

DOI: $10.37190 /$ arc210107

\title{
Bartosz Kaźmierczak*
}

\author{
Assistance of an expert in the participatory planning model \\ in the area included in the revitalisation programme in view \\ of the desired changes. \\ Based on the example of the district of Śródka in Poznań
}

\begin{abstract}
Introduction
There are no participatory methods developed in the Polish urban planning process that might engage the inhabitants into joint cooperation at all the stages of a planning process. This statement does not apply only to mandatory procedures that under Polish legislation require social participation at the stage of drawing up the planning documentation or documentation pertaining to revitalisation works. However, the above mentioned participatory planning should above all apply to factual inclusion of the voices of local communities in the legislative and decision making processes. The most frequent practice is to present the already worked up planning and design solutions that are subsequently consulted with the social groups. Such a practice is most often supported with the time pressure argument in reference to the EU funds application procedures. As a result, the term "participatory" planning becomes an empty phrase used to confirm that the consensus was reached in social negotiations [1]. Thus, the voice of local communities is rarely fully accounted for and it rarely has any major impact on the decision making process, in particular at the level of a given revitalisation programme implementation. The blame, however, should not be put on the self-governments only. As Mielczarek-Żejmo [2] states, involvement of a variety of entities into the decision making process should be based on effective management of complexity and diversity of conflicts and crises that may arise in reference to one area as well as on effective mana-
\end{abstract}

* ORCID: 0000-0001-8436-6963. Faculty of Architecture, Poznan University of Technology, e-mail: bartosz.kazmierczak@put.poznan.pl gement of diversity of opinions regarding social needs and development opportunities of a given zone.

The purpose of this article is to carry out a case study on Sródka district in Poznań to find answers to the question about the role of experts in participatory planning.

\section{Participatory method in the process of revitalisation}

Social participation in urban development facilitates proper diagnosis of problems and chances as well as the process of education, the exchange of know-how and good professional practices. Moreover, inclusion of a wide range of stakeholders into the stage of identification, planning, implementation and monitoring of the revitalisation or development works will elevate them to the rank of factual co-designers of the changes in their surroundings. Polish urban planning process has so far failed to work up participatory methods that might engage the inhabitants into joint cooperation at all the stages thereof.

Socialisation of the planning process at a number of stages shall be based on appropriate education of the local communities to ensure that they are prepared and ready to properly participate in the process. In particular, they should be ready to conduct substantive and responsible dialogue [3]. Four main categories may be distinguished from among good practices ensuring the factual socialisation of the urban development or revitalisation that will facilitate due education of the local communities to effectively participate in the planning process [4]. These are the techniques that develop:

1) understanding the complexity of the assessment perspectives, in particular the difference between the subjec- 
tive (your own) and objective (collective) perception of problems, needs and solutions;

2) abilities to recognise and compare places based on a wide perception of the local environment in view of its potential opportunities, not just problems and deficiencies;

3) ability to use the municipal information database: reading plans and referring them to a factual space; structuring the information coming from different sources, understanding how the municipal administration functions, etc.;

4) a collaborative approach to the planning process and proposing the desired, reasonable and feasible solutions.

Engaging diversified entities into the decision making process shall be founded on the searches for efficient management of complexity and diversity of the conflicts and crises that might arise in one place as well as the efficient management of diversity of opinions on social needs and development opportunities of a given area [2]. A social network is one of those theoretical perspecti ves that allow for defining rules applicable to combining forces in the process of urban development or revitalisation. Such networks assume a specific form of governance networks, which can be defined as a manner of creating and implementing public policies through the creation of the relations network between the authorities, entrepreneurs and key players in the civic society [5]. The operation of such cooperation network in the context of the activities intended for the purpose of conversion and development of the town is predetermined with the role of local leaders. Their role shall focus on the initiation of the said activities, regulation of their functioning and verification of their observance. The main idea of such networks is to engage into cooperation the right key players that have proper resources and know-how in order to meet defined targets. It is also important to define the framework of the cooperation network, in particular in the context of identifying the desired target activities, scope of competences and the manner of making decisions. Here, the experts can play an important role as the approval body, but more than just that, they can educate, integrate and coordinate the stakeholders in the process.

\section{Case study - Śródka}

Śródka is a small housing estate on the borderlines of Poznań downtown area, which has been the subject matter of many research works for many years now. The social, economic and spatial changes undergoing in the area are of interest to all the stakeholders that view revitalisation as an important regeneration process of degraded urban structures and fabric [6]. Since 2006, when the Municipal Revitalisation Program was adopted for the district of Śródka, this small housing area has become the core of research and a case study in respect of the implementation of revitalisation activities prescribed in the aforementioned revitalisation programme adopted by the authorities of Poznań. Opinions concerning the assessment of the effects of Śródka revitalisation have varied. Many researchers are critical of the effects of the activities undertaken within the framework of the programme in 2006, pointing out that they resulted in increased rents and pushed out the financially fragile inhabitants from the area [7], [8]. Nevertheless, we cannot overlook the positive spatial changes that have improved the aesthetics of development and public space or increased the functional attractiveness of the district owing to the opening of the Interactive Centre for the History of Ostrów Tumski (ICHOT). The process, furthermore, increased the awareness of the inhabitants and the entrepreneurs living and operating in Śródka in respect of the district contribution into the creation of the image of Poznań.

\section{Problems of local entrepreneurs}

Activities undertaken to revitalise degraded areas - in particularly those located in the central part of the city - must account for certain adverse phenomena inherent in increased attractiveness of an area under revitalisation. Increased public interest in a venue where cultural events take place, improvement of visual quality of urban space or creating certain social popularity trends may result in social conflicts or increase the abuse of particular interests [9]. In case of the district of Śródka, the stakeholders have many times successfully managed to balance the interests of respective groups, thus preventing any conflict escalation and loosening of the social bonds established with so much effort and involvement [10].

It has turned out that a conflict arose from a problematic issue that failed to be resolved at the very beginning of revitalisation and from a new situation that occurred due to unpredicted circumstances. Both situations underlay the escalating dissatisfaction of the entrepreneurs operating in the district of Śródka. The first one concerned the so far unsolved problem of transit through the housing estate and improper organisation of parking options. The second conflict developed unexpectedly when the owners, after the renovation of the façades of their tenement houses, demanded that the traffic lights operator that had used the elevations of the houses for the purpose of the installation of the lighting fixtures should reimburse the owners a part of the renovation costs. The operator did not have any proper agreements concluded in this respect and for this reason, refused to pay any compensation to the tenement house owners. They, in turn, refused to have the light fixtures installed on the elevations of their buildings. Due to the conflict, spatial attractiveness of Śródka declined and, as per the claims of local entrepreneurs, translated into the decreased revenue generated from business operations, mainly in the catering sector. Some of the local restaurant owners decided to undertake their own initiative to rescue their businesses. Unfortunately, their ideas to support respective businesses failed to account for the interests of other local entrepreneurs, and even the inhabitants of Śródka, the main users of the district space. Two extreme approaches could be observed among members of the local community:

1. The approach taken by the entrepreneurs: "I am strong and I have the initiative, thus, I convert the actual surroundings as I deem fit".

2. The approach taken by the local activists: "I am an important part of the urban fabric, where I operate, and 
Fig. 1. A map showing the approved in 2017 by the Town Hall in Poznań "Social concept of changes in the organisation of traffic in the district of Sródka", where transit through the district centre is no longer admissible (source: https://www.poznan.pl/ $\mathrm{mim} / \mathrm{s} 8 \mathrm{a} /$ projekt-srodka, p, 1025,5634.html; accessed: 14.03.2021)

I1. 1. Mapa przedstawiająca zatwierdzoną w 2017 r przez Urząd Miejski w Poznaniu „Społeczną koncepcję zmian w organizacji ruchu na Śródce”,

w której nie dopuszcza sie już tranzytu przez centrum dzielnicy (źródło: https://www.poznan.pl/ $\mathrm{mim} / \mathrm{s} 8 \mathrm{a} /$ projekt-srodka $\mathrm{p}, 1025,5634 . \mathrm{html}$ data dostępu: 14.03.2021)

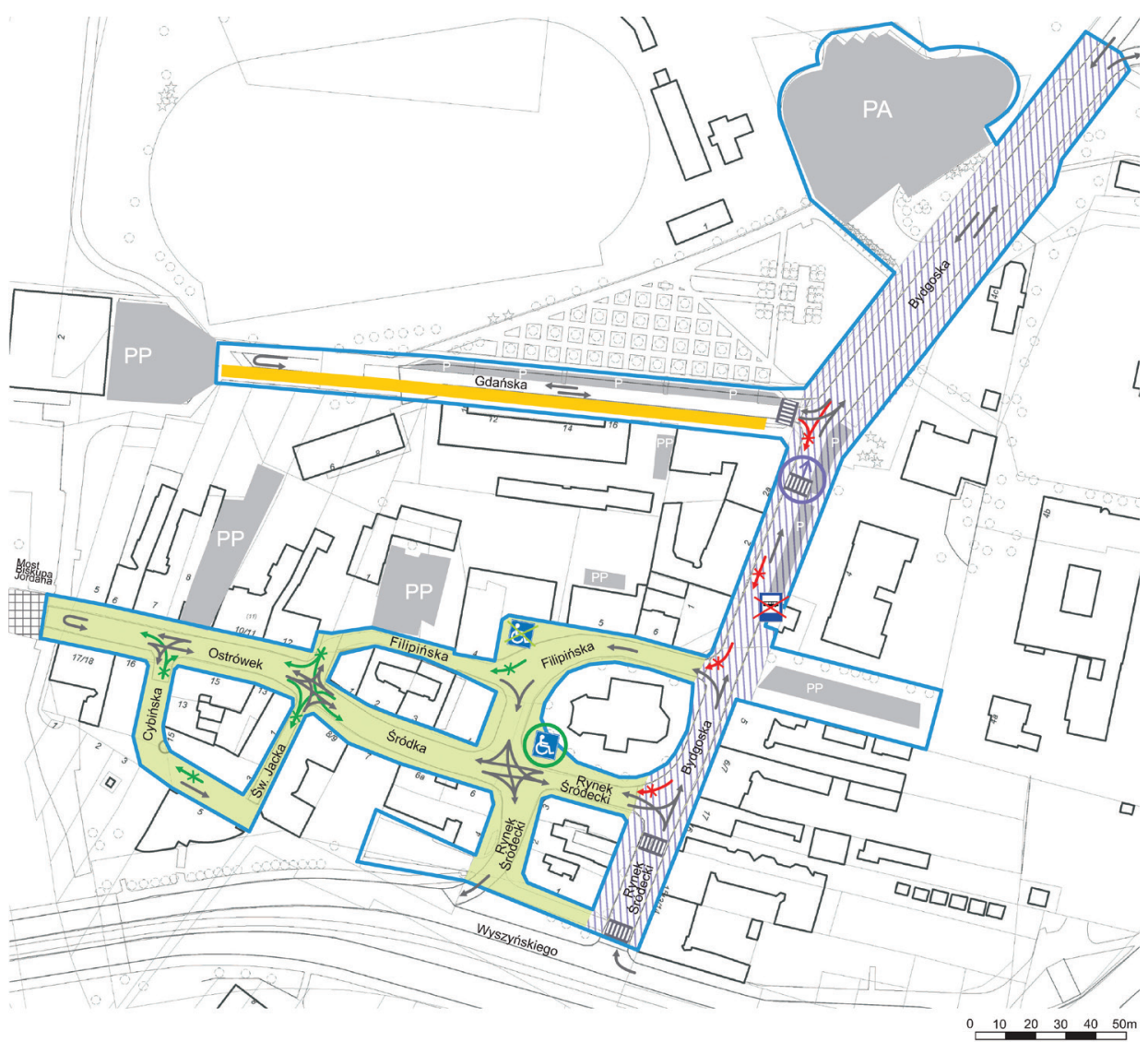

because I am the beneficiary of this place, I am partially responsible for it".

Thus, the question arises on the conditions to be met for the two groups of stakeholders taking the two extreme approaches but declaring to have the same needs to get together and discuss the issue amicably.

Activation of local entities and social leaders translates into increased civic awareness and creates the need for a dialogue. In the district of Śródka, in order to resolve the conflict and to agree on the right solution in the best interest of the inhabitants, it was necessary to get the municipal authorities involved. A dedicated workshop was organised and the invited experts ${ }^{1}$ were expected to resolve the dispute that had arisen in the local community, in a manner facilitating the strengthening of social bonds and mutual trust.

\section{Workshop meeting. \\ Assumptions, course of development, conclusions}

The Revitalisation Branch of the Poznań Town Hall², the Board of the Housing Estate "Ostrów Tumski Sródka - Zawady - Komandoria" and the Society of the Friends of Śródka and the neighbouring areas called "Śródeja"

\footnotetext{
1 The invited experts: Bartosz Kaźmierczak and Sławomir Palicki were members of the group of experts, actively engaged in the activities aimed to implement the Sródka district Revitalisation Programme in the years 2008-2019.

2 The Head of the Branch Office was at the time Lech Podbrez, an architect.
}

came up with the idea of the workshop meeting and then organised it. The workshop attracted property owners and administrators as well entrepreneurs operating in the district of Śródka (hotel owners, restaurant owners and retail store owners), as well as local activists. The purpose of the workshop was to agree on the most crucial threats and opportunities for the businesses in Śródka, options of creating the image of entrepreneurial spirit of the district of Śródka and a possible scope of cooperation.

To optimally use the time individual participants could devote to participate in the workshop, its preliminary priority assumptions had been worked up in advance. Before commencing work with any group of participants, the organisers approved of a postulate of a wide range of cooperation at the stage of conceptions and of the principle that joint interest shall prevail over particular interests in the selection of solutions to be implemented. It was agreed that the main task of the meeting was to make the participants aware that every one shall contribute to the discussion on the desired changes because the solutions worked out jointly shall serve the common welfare. Thus, if every participant declared that $\mathrm{s} /$ he needed to maximise the profits generated from business activity run in Śródka, then, s/he should make a relevant financial investment or put an effort in the organisation of joint initiatives, adequately to his/her declaration. The meeting was scheduled for three hours; the planned workshop was divided into two thematic groups: diagnosis - listing the problems; and directions of changes - during this part of the workshop the participants searched for possible solutions to the prior listed problems. 


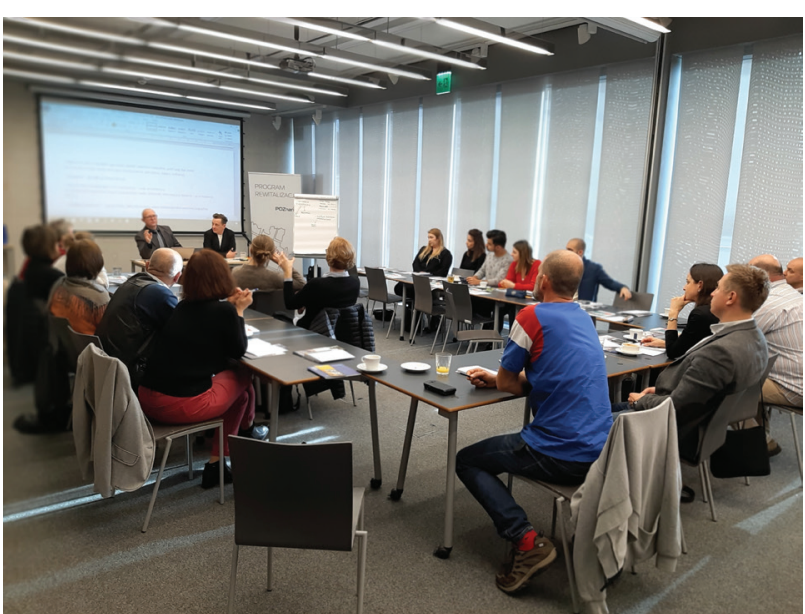

Fig. 2. Participants of the workshop - representatives of local entrepreneurs, housing estate board and local activists (photo by L. Podbrez)

Il. 2. Uczestnicy warsztatów - przedstawiciele lokalnych przedsiębiorców, rady osiedla i lokalnych aktywistów (fot. L. Podbrez)

The first part of the workshop started with two short presentations by the experts ${ }^{3}$ who chaired the event. The first presentation recalled the leading role of the district of Sródka and its neighbouring area of Ostrów Tumski (the cradle of the Polish state) in the development of Poznań. The second part focused on the methodology of running discussions and reaching consensus. After the introductory part the participants were asked to report problems that for them directly translated into the reduced income generated from the business activities they ran in Sródka and to list the assets of the location. Spontaneously voiced opinions by individual participants in the course of the discussion were recorded. The workshop chairmen refrained from moderating the voices raised, but only noted down the drawbacks in red and the benefits in green.

The concerns raised included voices on several problematic issues. The most important one, being the direct reason why the workshop meeting was organised, was the street lighting. The organisers hoped the participants would be able to arrive at a consensus. After dusk, it was pitch dark in Śródka. Lack of lights at the section from the Cathedral to Śródka Roundabout discouraged any visitors from entering the area. The lighting arrangement should invite the visitors, whereas there was no such incentive, the space lacked coherence and emitted no express signals that might "invite" visitors to Śródka. Poor recognisability of the place affects the perception of what the district has to offer (as a hidden/unknown offer), whereas the existing spatial arrangement only underlines the separation of Sródka with the urban planning borderlines between this district and Ostrów Tumski and next the Old Market Square. Tourist information and promotion services seem to insufficiently propagate what Śródka has to offer (thus,

3 The first to take floor was B. Kaźmierczak, a $\mathrm{PhD}$, engineer architect, to be followed by Sławomir Palicki, $\mathrm{PhD}$, specialist in economy. it remains hidden/unknown). The recognisability of the place is poor, its identity symbols fail to be widely recognised, e.g., the 3D mural, which fails to be described in guide books and the tourists often do not know where to look for it. As far as historical sites are concerned - the Church of St. Margaret is inaccessible to the public. The entrance to its chapel and to the yard is usually closed. What is more, the Polish-Catholic Saint Casimir church is equally inaccessible and unknown, similarly to the school for the deaf children and the Cathedral School, which often hold a variety of cultural events. The exchange of information on the events organised in Śródka and Ostrów Tumski was also poorly rated. In this scope consensus had failed to be reached by the two administrative areas, which, despite their close vicinity, seemed to operate separately. From the perspective of servicing the tourist traffic, Śródka was noted to clearly lack the tourist infrastructure in the basic form of small architecture, i.e., benches, rubbish bins or cash dispensing machines.

Another issue raised and highlighted, in particular by the representatives of the housing estate board and "Śródeja" Society, was the leading residential function of Śródka. Thus, the two bodies maintained that the late opening hours of restaurants and bars, similarly to those in the Old Market Square in Poznań, were improper because it was in the best interest of the residents that Sródka should attract the visitors during the day and not at night. The inhabitants were the hosts in their district, therefore peaceful resolution of conflicts between them and the visitors should be viewed as a necessity. The restaurant owners agreed with the statement and acknowledged the fact. They, however, stressed that at weekends their businesses located in Śródka generated the highest turnover. They also named the events that adversely affected their business operations. The marathon was listed as an event generating great losses for the entrepreneurs (on average there are approx. five such events annually). During such events, transport to Śródka is blocked and social media especially contribute to the atmosphere of panic, predicting total traffic paralysis, and recommend that the visitors should avoid going to Śródka on such occasions. It often happens that the circulation of the information about such events is inefficient, the public is not informed about them with due notice and there is no reliable information about bypasses or alternative access roads leading to Śródka. The information on available transport options to Śródka is similarly poorly disseminated, this includes no information on bus or passenger car park options or on the car park at the back of the Cathedral in Ostrów Tumski. Car park space as such was assessed as sufficient because at weekends the car park near the school for the deaf can be used if needed. The participants, however, acknowledged the fact that car park places need to be clearly delimited as the cars tend to be parked "wherever possible" - even on the pavements; this renders the impression of chaos, disorder, lack of aesthetics, which, in view of the perception of the quality of space, translates into its negative image and, moreover, results in the obstruction of vehicle and pedestrian traffic. The transit traffic rush hours in Śródka 
Table 1. Summary of the comments reported in the form of SWOT analysis (elaborated by S. Palicki, B. Kaźmierczak) Tabela 1. Podsumowanie uwag zgłoszonych w formie analizy SWOT (oprac. S. Palicki, B. Kaźmierczak)



are the morning and the afternoon hours. This is a major problem of the district and requires changes in the traffic organisation. Śródka is accessible by car only from two directions, but the cyclists using Wartostrada (the cycleway along the Varta river) fail to be directed to Śródka, in the opinion of the restaurant owners, this reduces the earning opportunities of the restaurants.

Later on, the experts and the participants moved to classify the comments and observations using the standard marketing evaluation method, i.e., the SWOT (strengths, weaknesses, opportunities, threats) analysis. After relevant table columns were appropriately filled up, all the participants were asked to assign weight (in the scale 1-5) to individual comments in order to prioritise the advantages and drawbacks.

The second part of the workshop was dedicated to the search for solutions, which, in view of the reported problems could positively affect business operations of Śródka entrepreneurs. The participants were free to voice their ideas, which were not moderated by the chairmen. The following ideas were proposed (according to their sequence):

1) ensure continuous lighting arrangement that would link the entire Royal-Imperial Route (the Old Market Square, Chwaliszewo, Ostrów Tumski, Śródka),

2) compile a guide book about Sródka that would be continuously available at any tourist information office in Poznań,

3 ) use the mural in promotional and informative materials/leaflets,
4) use slogans including the district name, i.e. Śródka, "Śródka - the smallest town in Poland", "Śródka - this is where Poland began",

5) make the historical sites in Sródka available to the visitors - including the sacral facilities,

6) create new signs in the city space (new direction signs, following the example of the mermaid in Copenhagen),

7) stress the uniqueness of Śródka district niche offer, intended for individuals but not for the masses (quiet nights, busy days),

8) attract pedestrians, yet leave and clearly delimit the car park places,

9) remove the transit traffic,

10) create a formal "incentive" that will invite cyclists and pedestrians from the "Wartostrada" side,

11) enhance what Środka has to offer by its "unification" with Ostrów Tumski and by coordination of joint activities,

12) strengthen the social impact of Saint Peter and Paul Day, the holy patrons of Poznań (as an alternative or supplementary event to St. Martin's day),

13) coordinate - to an extent larger than before - the organisation of events and celebrations in respect of religious, culinary and cultural events which take place in Sródka,

14) organise street stall sales (fairs, weekend sales, flea markets or antique fairs [china, clocks], militaria fairs),

15) open a car park near the school for the deaf children, 
16) bring more life to the district thanks to restaurant outdoor patios,

17) create tourist-friendly infrastructure in the form of small architecture such as benches, rubbish bins as well as information boards (maps/information boards/road signs/ tourist information about given facilities) with the support of the Poznań Local Tourist Organization (PLOT),

18) encourage new investors - open up to new ideas,

19) create an attractive image of the district though social media - "Talking about Śródka" - a quasi-official forum for the exchange of opinions and a form of supporting the business interests of the entrepreneurs operating in Sródka in cooperation with the Board of the Housing Estate and the Society of the Friends of Śródka - "Śródeja", etc.

\section{The results of the workshop}

- an expert's attempt to classify the ideas voiced

In accordance with the definition [11] of the types of activities undertaken in revitalisation projects:

- "Hard" activities are related to the improvement of the condition of infrastructure and development, e.g., tangible structures,

- "Soft" activities are connected with the improvement of the condition of the local community and its growth opportunities, including recovery from a crisis (in the context of social and economic situation).

Nineteen of the submitted ideas were, thus, divided into "hard" and "soft" activities (in 8 to 11 proportion). The following ideas were classified into the first group ("hard activities"): 1, 6, 8, 9, 10, 15, 16, 17, whereas the second group ("soft activities") contained: 2, 3, 4, 5, 7, 11, $12,13,14,18,19$.

The ideas could also be grouped with the use of another criterion, i.e. the types of problems to be solved by the ideas proposed. Moreover, the strengths and weaknesses, identified within the SWOT analysis, can become further criteria for the division of the proposed ideas. As a consequence, the ideas can be divided into four strategies:

- spatial accentuation of a place and its assets $(1,6$, $16,17)$

- using the tourist potential of the area $(2,3,4,5,7)$,

- minimising the negative impact of motor vehicle transport $(8,9,14,15)$,

- integration of undertakings made by the entities operating in the district $(11,12,13,18,19)$.

To facilitate the verification of respective ideas, the degree of their complexity, their potential and limitations, the experts defined 5 assessment criteria:

- continuity, potential of maintaining effects - the criterion, which helps us answer the question whether a given idea entails a one-time, irregular activity or a regular one. The assumption was that regular, periodic activities shall contribute more to the maintenance of the results in time,

- potential conflicts/concessions/consensuses - the criterion based on the search for solutions that raise no reservations. Any activities that might be a source of any potential conflicts shall be dismissed and the entrepreneurs shall focus mainly on those ideas that stand a chance of reaching a consensus. Implementation of solutions that have a potential for concessions could also be considered, however, then it shall be assumed that their results might turn out unsatisfactory,

- costs to be incurred and the sources of their financing are an important criterion of the assessment of the ideas in view of their feasibility. Solutions that involve high level of costs and depend on the investor's outlay will have little chances of implementation if the investor does not gain any direct benefits from the investments. The ideas that take precedence are those that do not require excessive costs to be incurred or those that might attract a group of investors willing to partially cover the costs of the investment,

- the criterion of division of tasks and their contractors describes the complexity degree of scheduling the factual activities necessary for the attainment of goals proposed within the framework of given ideas. The more complex the undertaking - i.e., requiring the completion of many tasks and engaging a great number of contractors - the more difficult the desired goal is to attain. The best ideas are those that can be entrusted to contractors already performing similar works, and the planned tasks will only extend the scope of works that have been started already,

- the last assessment criterion defines the tasks of key importance for the attainment of the desired goal. Based on Pareto principle ( 80 to 20 principle), $20 \%$ of the ideas are assumed to be selected as being capable of rendering $80 \%$ of the pursued goals.

The fact that experts were appointed to engage into the urban planning issues of the district of Śródka as early as in 2008 has contributed to the strengthening of the social network of the stakeholders, including the executive body of the self-government, local activists, leaders and entrepreneurs, who have successfully exchanged their knowhow on the changes undergoing in the revitalised areas from their own perspectives. Owing to this collaborative approach, the stakeholders have succeeded in creating the atmosphere of mutual trust and actively and creatively cooperated in the process of identifying the problematic issues and proposing solutions thereto. The role of an expert, in this case, was not limited to designing the frames of the participatory planning. The invited experts also assisted the stakeholders in defining the assessment criteria, which allowed them to make objective decisions on possible strategies to be undertaken in order to meet the goals (Table 2).

\section{Conclusions}

The ideas proposed during the workshop are of double value. On the one hand, they are precise guidelines for future activities in reference to the organisation of space, and, on the other hand, they are the evidence that it is possible to work up joint strategies accounting for the needs of all the stakeholders. Participation of experts (neutral in respect to the problems) in the pursuit of joint solutions underlies the successful cooperation between the groups characterised with different standing as regards the space use. Such experts can work up relevant concessions for 
Table 2. Ideas assessment diagram (elaborated by B. Kaźmierczak, S. Palicki, L. Podbrez)

Tabela 2. Schemat oceny pomysłów (oprac. B. Kaźmierczak, S. Palicki, L. Podbrez)

\begin{tabular}{|c|c|c|c|c|c|}
\hline \multicolumn{6}{|c|}{ SOFT ACTIVITIES } \\
\hline New investors - opening up to new original ideas & 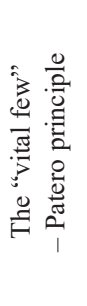 & 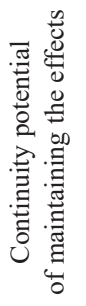 &  &  & 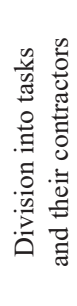 \\
\hline \multicolumn{6}{|l|}{ Ideas to standardise events/festivities - sacral, cultural, catering } \\
\hline $\begin{array}{l}\text { "Talking about Śródka [Śródka na językach]" - social media in t } \\
\text { of a quasi-official forum for the exchange of opinions; an associatic } \\
\text { society, board as a form supporting the business interests of the ent } \\
\text { operating in Śródka in cooperation with the Board of the Housin } \\
\text { and the Society of the Friends of Śródka - "Śródeja", etc. }\end{array}$ & & & & & \\
\hline \multicolumn{6}{|c|}{$\begin{array}{l}\text { Street stall sales (fairs, weekend sales, flea markets or niche events e.g. antique fairs: } \\
\text { china, clocks, militaria fairs, etc.) }\end{array}$} \\
\hline \multicolumn{6}{|l|}{$\begin{array}{l}\text { ENHANCEMENT OF THE DISTRICT OFFER BY ITS UNIFICATION } \\
\text { AND CONNECTION WITH OSTRÓW TUMSKI }\end{array}$} \\
\hline \multicolumn{6}{|c|}{$\begin{array}{l}\text { Organising/Increasing the attractiveness of the festivities of Saint Peter and Paul Day, } \\
\text { the holy patrons of Poznań (as an alternative or supplementary event } \\
\text { to the celebrations of St. Martin's Day) }\end{array}$} \\
\hline \multicolumn{6}{|l|}{$\begin{array}{c}\text { A GUIDE BOOK ABOUT ŚRÓDKA/TOURIST INFORMATION } \\
- \text { HISTORICAL SITES OF ŚRÓDKA }\end{array}$} \\
\hline \multicolumn{6}{|c|}{$\begin{array}{c}\text { "Śródka - the smallest town in Poland" (or rather: Śródka - the historical location } \\
\text { of Ostrówek - the smallest town in Poland, author's comment), } \\
\text { the place closely connected with the origins of the Polish state }\end{array}$} \\
\hline \multicolumn{6}{|l|}{ "Opening the historical sites" - including sacral buildings } \\
\hline \multicolumn{6}{|l|}{ Using the mural for the promotion purposes } \\
\hline \multicolumn{6}{|c|}{ HARD ACTIVITIES } \\
\hline \multicolumn{6}{|c|}{$\begin{array}{l}\text { Tourist-friendly infrastructure. Small architecture such as benches, rubbish bins as } \\
\text { well as information boards (maps/information boards/road signs) with the support of } \\
\text { the Poznań Local Tourist Organization (PLOT) }\end{array}$} \\
\hline \multicolumn{6}{|l|}{ NEW SIGNS IN CITY SPACE } \\
\hline \multicolumn{6}{|c|}{ Continuous lighting arrangement that would link the entire Royal-Imperial Route } \\
\hline \multicolumn{6}{|l|}{ Formal "invitation" from Wartostrada side } \\
\hline \multicolumn{6}{|l|}{$\begin{array}{l}\text { ATTRACTING PEDESTRIANS, LEAVING AND CLEARLY DELIMITING } \\
\text { THE CAR PARK PLACES }\end{array}$} \\
\hline \multicolumn{6}{|l|}{ reviving the street life thanks to restaurant outdoor patios } \\
\hline \multicolumn{6}{|l|}{ Banning the transit traffic in Środka district } \\
\hline Opening a car park near the school for the deaf children & & & & & \\
\hline
\end{tabular}

the postulates of the entrepreneurs to meet the conditions set forth by the local community and the formal requirements posed by the authorities.

Another important aspect of the research is its educational value. The entrepreneurs acknowledged the fact that cooperation with public institutions and the area inhabitants was not only necessary to reach the set goals - particularly in the area of the so-called "hard" activities connected with the development of the required infrastructure
- but was also a pre-requisite for creating the atmosphere of mutual trust which underlies the streamlining of Śródka community initiatives. The example described in the article is intended to emphasise the role of an expert in increasing the social awareness of the need to integrate tasks and synchronise activities undertaken within the framework of adopted strategies. Active engagement of experts has a potential of a synergy effect, strengthening the development opportunities of the entire district. To reach 
the set goals, it is important to stress that the community should participate in the process to the largest extent possible. A neutral and objective approach of the experts in the assessment of the proposed ideas, often perceived individually and selectively, makes a huge difference.

The participatory model in the planning of desired changes that includes the assessment of experts contributes to the right diagnosis of problematic issues and opportunities; it, furthermore, facilitates education, popular- isation of know-how and exchange of good professional practices. Moreover, inclusion of a wide group of stakeholders at the stage of identification, planning, implementation and monitoring of revitalisation or development activities makes the group members viable change promoters [12].

Translated by Barbara Wesolowska-Marszatek

\section{References}

[1] Miessen M., The Nightmare of Participation, MIT Press, Cambridge 2010.

[2] Mielczarek-Żejmo A., Sieci wspótrzadzenia w procesach rewitalizacji, "Rocznik Lubuski" 2019, t. 45, z. 2, 105-117.

[3] Przywojska J., Wspótzarzadzanie i partycypacja spoleczna w rewitalizacji, "Rocznik Lubuski" 2019, t. 45, z. 2, 21-34.

[4] Martyniuk-Pęczek J., Rembarz G., Urban mentoring jako nowa technika wspólpracy $w$ procesie planowania partycypacyjnego, "Biuletyn KPZK" 2016, nr 264, 119-146.

[5] Klijn E.H., Skelcher Ch., Democracy and governance networks: compatible or not?, "Public Administration" 2007, Vol. 85, Iss. 3, 587-608.

[6] Kaźmierczak B., Nowak M., Palicki S., Pazder D., Oceny rewitalizacji. Studium zmian na poznańskiej Śródce, Wydawnictwo Wydziału Nauk Społecznych UAM, Poznań 2011.

[7] Nowak M., Niezrealizowana rewitalizacja jako niedoskonała gentryfikacja. Analiza procesu ożywiania poznańskiej Śródki, "Ruch Prawniczy, Ekonomiczny i Socjologiczny” 2013, R. 75, z. 3, 229-249.
[8] Nowak M., Śródka po siedmiu latach rewitalizacji. Metateoretyczny wtręt $i$ interpretacja socjologii procesu ożywiania miasta, [in:] K. Derejski, J. Kubera, S. Lisiecki, R. Macyra (red.), Nowe życie w mieście? Dylematy rewitalizacji, Wydawnictwo Naukowe Wydziału Nauk Społecznych UAM, Poznań 2014, 49-70.

[9] Billert A., Problemy rewitalizacji Śródmieścia Poznania, "Kwartalnik Architektury i Urbanistyki” 2007, t. 52, z. 1-4, 72-80.

[10] Donderowicz M., Główczyński M., Wronkowski A., Partycypacja spoleczna w rewitalizacji - rola stowarzyszeń lokalnych na przykładzie Poznania, Problemy Rozwoju Miast, "Kwartalnik Naukowy Instytutu Rozwoju Miast" 2016, R. 13, z. 4, 41-51.

[11] Lorens P., Lokalny Program Rewitalizacji Miasta Płocka, [presentation], http://rozwojmiasta.plock.eu/wp-content/uploads/2015/10/ Borowiczki-6_10_2015.pdf [accessed: 6.07.2020].

[12] Przywojska J., Revitalisation Committee - a Form of the Comanagement of the Revitalisation Process on the Example of the City of Łódź, "Przedsiębiorczość i Zarządzanie" 2018, t. 19, z. 3, cz. 3, $15-26$.

\section{Abstract \\ Assistance of an expert in the participatory planning model in the area included in the revitalisation programme in view of the desired changes. Based on the example of the district of Śródka in Poznań}

This article presents the method of resolving conflicts arising around projects implemented in the area included in the revitalisation programme. The author presents the subject of social participation in the Central European context, in which the low level of social trust and the difficulty in making joint decisions in the spirit of consensus are characteristic. The aim of this article is to try to define the role of experts in the participatory planning model. The described case study allows for the assumption that in the search for the desired changes in the area covered by the revitalization program, the participation of not only stakeholders but also experts should be taken into account. Thanks to this approach, it becomes possible to articulate - often contradictory needs, which in turn increases the chances for the implementation of postulates submitted by stakeholders. Real social participation in the decision-making process regarding changes related to revitalization is possible thanks to the involvement of experts who are, in a way, "shop stewards" who guarantee not only an appropriate level of debate but also help to objectify the developed postulates.

Key words: participatory planning, expert assessment, revitalization, post-communist countries, Central Europe

\section{Streszczenie}

Pomoc ekspercka w partycypacyjnym modelu planowania pożądanych zmian w obszarze objętym programem rewitalizacji. Przyklad poznańskiej Śródki

W artykule omówiono sposób rozwiązywania konfliktów pojawiających się wokół projektów realizowanych na obszarze objętym programem rewitalizacji. Autor przedstawia w nim problematykę partycypacji społecznej w kontekście środkowoeuropejskim, dla którego charakterystycznym elementem jest niski poziom zaufania społecznego oraz trudność w podejmowaniu wspólnych decyzji w duchu konsensusu. Celem artykułu jest próba określenia roli ekspertów w partycypacyjnym modelu planowania. Opisane studium przypadku pozwala przyjać założenie, że w poszukiwaniu pożądanych zmian w obszarze objętym programem rewitalizacji należy uwzględnić udział nie tylko interesariuszy, ale także ekspertów. Dzięki takiemu podejściu możliwe staje się wyartykułowanie - często sprzecznych ze sobą - potrzeb, co w konsekwencji zwiększa szanse na urzeczywistnianie i realizację zgłoszonych przez interesariuszy postulatów. Realny udział społeczny w procesie decyzyjnym dotyczącym przemian związanych z rewitalizacją jest możliwy dzięki zaangażowaniu ekspertów, którzy są niejako „mężami zaufania”, gwarantującymi nie tylko odpowiedni poziom debaty, ale również pomoc w obiektywizacji wypracowanych postulatów. 